ARTICLE

\title{
Carbon emission from Western Siberian inland waters
}

\author{
Jan Karlsson (1) ${ }^{1 凶}$, Svetlana Serikova (1) ${ }^{1,2}$, Sergey N. Vorobyev ${ }^{3}$, Gerard Rocher-Ros (1) ${ }^{1}$, Blaize Denfeld ${ }^{1,4} \&$
} Oleg S. Pokrovsky 3,5,6

High-latitude regions play a key role in the carbon (C) cycle and climate system. An important question is the degree of mobilization and atmospheric release of vast soil $C$ stocks, partly stored in permafrost, with amplified warming of these regions. A fraction of this $C$ is exported to inland waters and emitted to the atmosphere, yet these losses are poorly constrained and seldom accounted for in assessments of high-latitude $C$ balances. This is particularly relevant for Western Siberia, with its extensive peatland $C$ stocks, which can be strongly sensitive to the ongoing changes in climate. Here we quantify $\mathrm{C}$ emission from inland waters, including the Ob' River (Arctic's largest watershed), across all permafrost zones of Western Siberia. We show that the inland water $\mathrm{C}$ emission is high (0.08-0.10 $\mathrm{Pg} \mathrm{C} \mathrm{yr}{ }^{-1}$ ) and of major significance in the regional $C$ cycle, largely exceeding (7-9 times) $C$ export to the Arctic Ocean and reaching nearly half (35-50\%) of the region's land C uptake. This important role of $\mathrm{C}$ emission from inland waters highlights the need for coupled land-water studies to understand the contemporary $\mathrm{C}$ cycle and its response to warming.

\footnotetext{
${ }^{1}$ Climate Impacts Research Centre (CIRC), Department of Ecology and Environmental Science, Umeå University, Linnaeus väg 6, 90187 Umeå, Sweden. ${ }^{2}$ Swedish Geotechnical Institute, Olaus Magnus väg 35, 58193 Linköping, Sweden. ${ }^{3}$ BIO-GEO-CLIM Laboratory, Tomsk State University, Lenina 36,634 050 Tomsk, Russia. ${ }^{4}$ Swedish University of Agricultural Sciences, Lennart Hjelms väg 9, 75651 Uppsala, Sweden. ${ }^{5}$ GET UMR 5563 CNRS, Geoscience and Environment, University of Toulouse, 14 Avenue Edouard Belin, 31400 Toulouse, France. ${ }^{6}$ Institute of Ecological Problems of the North, N. Laverov Federal Center for Integrated Arctic Research, Russian Academy of Sciences, Nab. Severnoi Dviny 23, 163000 Arkhangelsk, Russia. ${ }^{凶}$ email: jan.p.karlsson@umu.se
} 
$\mathrm{N}$ orthern high-latitude regions are covered by numerous rivers $^{1}$ and lakes ${ }^{2}$, together occupying up to $\sim 16 \%$ of the land area $^{3}$. At the same time, these regions store a significant amount of carbon $(\mathrm{C})(\sim 1672 \mathrm{Pg} \mathrm{C}), \sim 88 \%$ of which is stored in perennially frozen ground-permafrost ${ }^{4,5}$. At present, warming has accelerated in high-latitude regions with the mean annual temperature rising twice as fast as the global average ${ }^{4,6}$, making previously frozen permafrost vulnerable to thaw ${ }^{3,7}$. When permafrost thaws, it exposes substantial quantities of organic $\mathrm{C}$, resulting in $\mathrm{C}$ degradation and atmospheric release of carbon dioxide $\left(\mathrm{CO}_{2}\right)$ and methane $\left(\mathrm{CH}_{4}\right)^{6}$. Large quantities of terrestrial inorganic and organic $\mathrm{C}$ are also exported to inland waters ${ }^{8,9}$, leading to additional $\mathrm{CO}_{2}$ and $\mathrm{CH}_{4}$ emission from the water surface into the atmosphere. The $\mathrm{C}$ emission from inland waters is a substantial component of the global $\mathrm{C} \mathrm{cycle}^{10-13}$, yet for highlatitude regions such assessments are scarce ${ }^{14,15}$ and generally restricted to small catchments ${ }^{16,17}$, implying major uncertainties in the understanding of the high-latitude $\mathrm{C}$ cycle and its feedback on the climate system ${ }^{18}$.

Western Siberia with its extensive peatland area $(\sim 0.6$ out of $\sim 3.6$ million $\left.\mathrm{km}^{2}\right)^{19}$ containing vast organic C stocks $(\sim 70 \mathrm{Pg} \mathrm{C})^{19,20}$

\section{a}

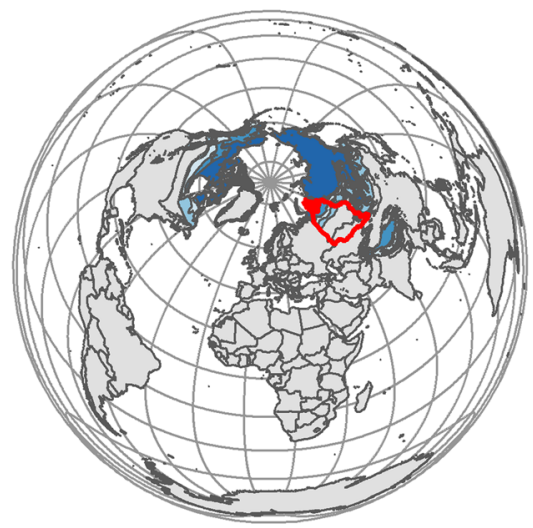

C

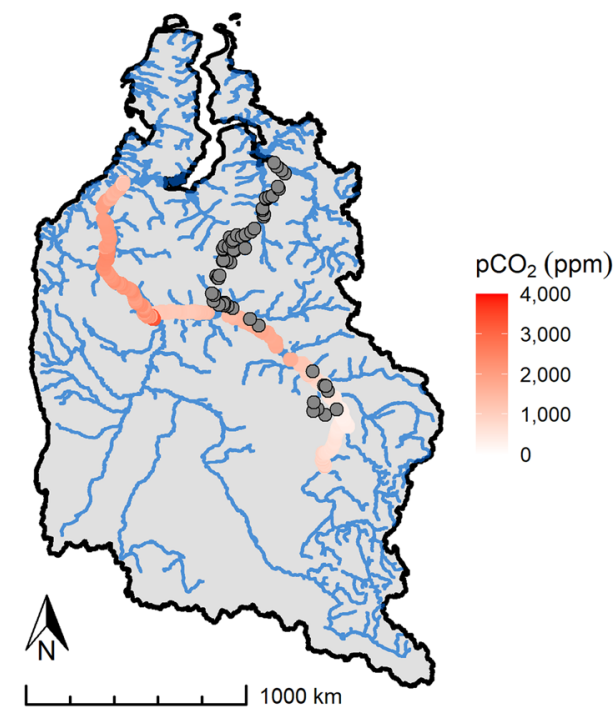

partly underlain by permafrost (Fig. 1) is of particular interest in the high-latitude $\mathrm{C}$ cycle. Permafrost in Western Siberia is vulnerable to thaw and has been degrading over the last few decades ${ }^{21}$. Also, Western Siberia harbors the largest Arctic watershed, the Ob' River, which is the second largest freshwater contributor to the Arctic Ocean $^{22}$ and is one of the few Arctic rivers that traverse through all permafrost zones along its course (from permafrost-free to continuous permafrost zone). Importantly, no direct $\mathrm{C}$ emission estimate exists for inland waters of Western Siberia. Siberian systems have been included in global inland water $\mathrm{C}$ emission estimates ${ }^{10}$, but these are based on few indirect (calculated gas concentration and modeled fluxes) snapshot data with very low spatial and temporal resolution that have been found to introduce large uncertainties and cannot adequately capture annual $\mathrm{C}$ emissions ${ }^{23-26}$. Given the region's large $\mathrm{C}$ stock and its overall sensitivity to warming, there is a clear need to estimate Western Siberian inland water $\mathrm{C}$ emission to constrain its role in present and future highlatitude and global $\mathrm{C}$ cycles.

Quantification of inland water $\mathrm{C}$ emission requires measurements of $\mathrm{C}$ emission rates and water surface areas of streams, rivers, ponds, and lakes-data that are scarce and geographically
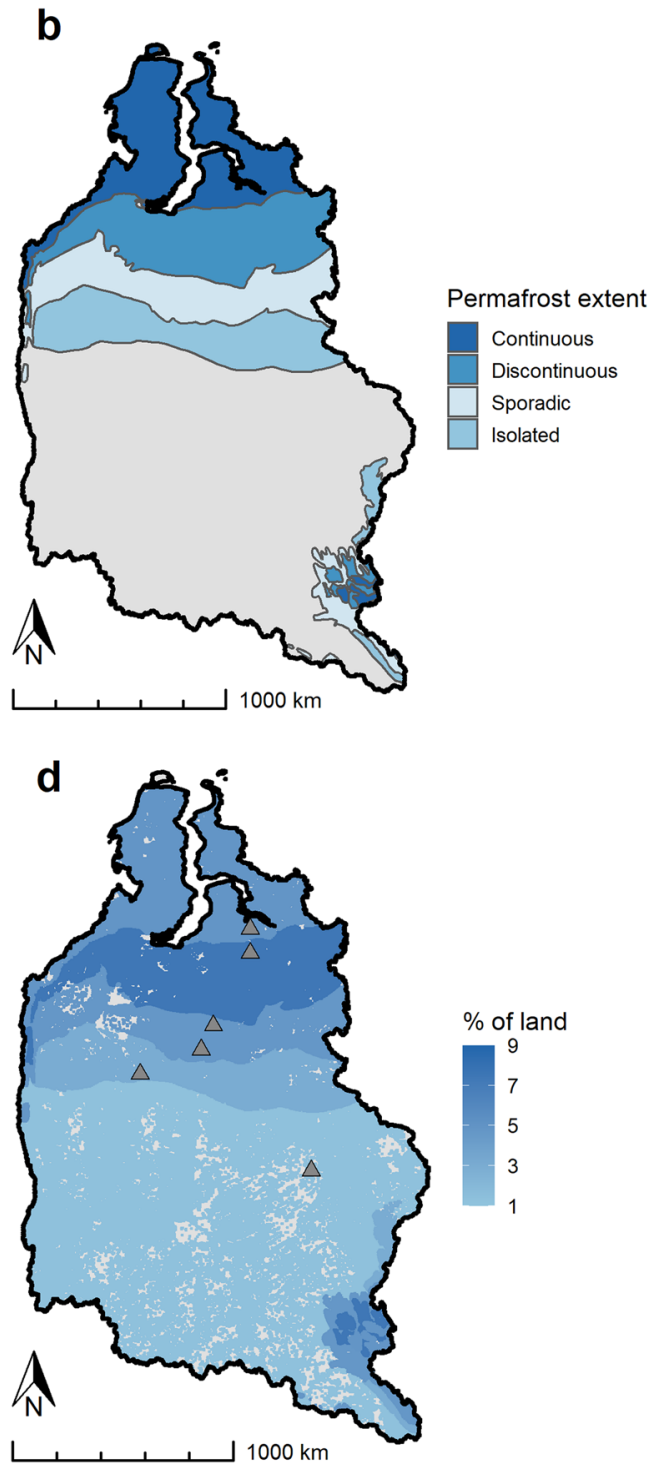

Fig. 1 Characteristics of the study area. Map of Western Siberia with a location of the $\mathrm{Ob}^{\prime}$, Pur, and Taz River basins (red line), b permafrost extent ${ }^{51}$, c partial pressure of carbon dioxide $\left(\mathrm{pCO}_{2}, \mathrm{ppm}\right)$ in the $\mathrm{Ob}^{\prime}$ main channel (red gradient bar), distribution of main river network (blue lines) ${ }^{1}$ and location of 58 study rivers (gray circles), d lake abundance ${ }^{2}$ and location of 6 sites (gray triangles) with 89 study lakes. 
biased, thus limiting assessments of the role of inland water $\mathrm{C}$ emission at a regional scale. In this work we used new and recent estimates of inland water C emission rates (collected from 2014 to 2016) and areas across all permafrost zones of Western Siberia to quantify the total annual $\mathrm{C}$ emission from Western Siberian inland waters. Specifically, we used recently published $\mathrm{C}\left(\mathrm{CO}_{2}+\right.$ diffusive $\mathrm{CH}_{4}$ ) emission rates from 58 rivers ${ }^{27}$ and 89 ponds and lakes 28,29 (hereby denoted "lakes" to distinguish from the extrapolated ponds, see below) covering a wide range of river (catchment area 2-150,000 $\mathrm{km}^{2}$ ) and lake (lake area 0.0001-1.2 $\mathrm{km}^{2}$ ) sizes and spanning a full gradient in permafrost extent (over $2000 \mathrm{~km}$ distance, Fig. 1 and Supplementary Table 1). We also included new estimates of $\mathrm{C}$ emission rates from the main channel of the Ob' River based on the first-ever direct continuous measurements of partial pressure of $\mathrm{CO}_{2}\left(p \mathrm{CO}_{2}\right)(1546 \pm 882 \mu \mathrm{atm}$, mean \pm s.d., Fig. 1) and regional gas transfer coefficient $(k)$ data. We obtained river and lake water surface areas in the Ob' River basin and two other major Western Siberian rivers (Pur and Taz) from published databases ${ }^{1,2}$ and upscaled rivers and lakes $C$ emission rates within each permafrost zone. Because the databases did not cover water surface areas of streams (lotic systems $<90 \mathrm{~m}$ wide) and the smallest ponds (lentic systems $<0.01 \mathrm{~km}^{2}$ ), we estimated these areas using Pareto law ${ }^{1,30,31}$ and upscaled streams and ponds $\mathrm{C}$ emission rates to the extrapolated areas. We summed $\mathrm{C}$ emission from all inland waters (rivers, streams, lakes, ponds) and assessed uncertainties using standard error propagation methods. The results allowed us to make the first assessment of the role of inland waters in the $\mathrm{C}$ cycle in one of the least studied but largest northern ecosystem in the world undergoing rapid permafrost thaw.

\section{Results and discussion}

We found that $\mathrm{C}$ emission rates from rivers are $\sim 4$-fold greater than $\mathrm{C}$ emission rates from lakes, resulting in greater yearly rates of $\mathrm{C}$ outgassing from lotic systems (rivers: $0.9 \pm 0.5$, lakes: $0.2 \pm$ $0.1 \mathrm{~kg} \mathrm{C} \mathrm{m}^{-2} \mathrm{yr}^{-1}$, mean \pm s.d.) (Fig. 2). Taken together inland waters (excluding streams and ponds) cover $\sim 5.2 \%$ of Western Siberia, with lakes $\left(\sim 171,000 \mathrm{~km}^{2}\right)$ accounting for a major fraction of the landscape compared to rivers $\left(\sim 20,000 \mathrm{~km}^{2}\right)$ (Table 1). The combined rivers and lakes $\mathrm{C}$ emission from Western Siberia was $0.050( \pm 0.007) \mathrm{Pg} \mathrm{C} \mathrm{yr}^{-1}$ and showed not only high values across the entire region, but also differences among permafrost zones (Fig. 2) $(H=242.67, P<0.05)$. The $\mathrm{C}$ yield (the total $\mathrm{C}$ emission from inland waters scaled to the land area) increased with increasing permafrost extent and reached its maximum in the discontinuous permafrost zone (Fig. 2) $(H=1556, P<0.05)$. This pattern is a consequence of particularly high rates of $C$ emission from lakes in the permafrost-rich zones combined with a large fraction of land area covered by lakes, while rivers contribute less to the $\mathrm{C}$ yield and exhibit no clear trend across permafrost zones. Such increase in $C$ yield emphasizes the fact that, not only warm, but also cold permafrost-rich areas of Western Siberia are important contributors to the overall high inland water $\mathrm{C}$ emission from this region.

When assessing the magnitude of inland water $\mathrm{C}$ emission across Western Siberia we used published measurements of $\mathrm{C}$ emission rates and areas. However, these estimates do not include the areas of the smallest streams and ponds, which are commonly the most abundant water bodies in the landscape ${ }^{2}$ and potentially important sources of $\mathrm{C}$ to the atmosphere $\mathrm{e}^{16,32}$. By extrapolating the areas of small systems ${ }^{1,30,31}$, the total lotic and lentic areas increased by $\sim 1$.6-fold $\left(33,390 \mathrm{~km}^{2}\right)$ and $\sim 2$.4-fold $\left(425,986 \mathrm{~km}^{2}\right)$, respectively, and increased the proportion of land occupied by water to $\sim 12 \%$. With the full size range of systems included, the $\mathrm{C}$ emission from inland waters increased $\sim 2$-fold, to $0.032( \pm 0.005)$ and
$0.071( \pm 0.012){\mathrm{Pg} \mathrm{C} \mathrm{yr}^{-1}}^{-1}$ for lotic and lentic systems, respectively (Fig. 3 and Table 1). The $\mathrm{C}$ emission from lotic systems was nearly equal between streams $\left(0.013 \pm 0.003 \mathrm{Pg} \mathrm{C} \mathrm{yr}^{-1}\right)$ and rivers

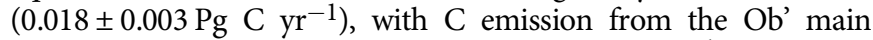
channel accounting for $24 \%\left(0.004 \pm 0.001 \mathrm{Pg} \mathrm{C} \mathrm{yr}^{-1}\right)$ of river C emission. The $\mathrm{C}$ emission from lakes was slightly lower than from small ponds $\left(0.032 \pm 0.006\right.$ and $0.039 \pm 0.010 \mathrm{Pg} \mathrm{C} \mathrm{yr}^{-1}$, respectively) (Table 1). Taken together, the total $\mathrm{C}$ emission from Western Siberian inland waters amounted to $0.104( \pm 0.013){\mathrm{Pg} \mathrm{C} \mathrm{yr}^{-1}}^{-1}$ (Fig. 3).

Our estimate for $\mathrm{C}$ emission from Western Siberian inland waters is greater than previously thought ${ }^{10,33}$. Specifically, mean $p \mathrm{CO}_{2}$ concentration, mean $\mathrm{CO}_{2}$ emission rate, and river $\mathrm{C}$ emission are $\sim 3, \sim 6.3$, and $\sim 4.6$-fold greater, respectively, than earlier assessment inferred from indirect observations and modeling ${ }^{10,33}$. Also, our estimate for total $\mathrm{C}$ emission from Western Siberian inland waters is $\sim 1.4$-fold greater than total C emission for this region and is $\sim 2.6$-fold greater than total $\mathrm{C}$ emission from other major Russian permafrost-draining rivers (i.e., sum of Kolyma, Lena, and Yenisei Rivers, 0.04 $\left.\mathrm{Pg} \mathrm{C} \mathrm{yr}^{-1}\right)^{10}$ derived based on modeling. Likewise, total $\mathrm{C}$ emission from Western Siberian inland waters is $\sim 4.2$-fold greater than total inland water $\mathrm{C}$ emission from the permafrost-affected Yukon

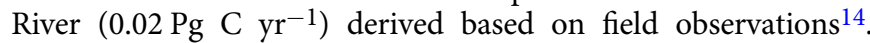
These comparisons emphasize not only the fact that $\mathrm{C}$ emission from Western Siberian inland waters is high, but also highlight the need for additional regional estimates of inland water $\mathrm{C}$ emission from other major watersheds to better constrain their role in the global $\mathrm{C}$ cycle.

The results of this study are based on an extensive dataset with direct measurements of $\mathrm{C}$ emission rates covering a wide range of river and lake sizes and spanning over a complete permafrost gradient of Western Siberia. Yet, our estimate of total C emission from Western Siberian inland waters contains uncertainties related to practical constraints in carrying out measurements of $\mathrm{C}$ outgassing rates at higher spatial and temporal resolution. Measurements focused on key periods (spring, summer, autumn) likely captured main variability in $\mathrm{C}$ emission rates $^{24,34}$, but still, collection of more temporally resolved data, especially in smaller systems, is needed to optimize sampling protocols for future C outgassing estimates. Furthermore, although the relatively homogenous geomorphology, soil type, and lithology of Western Siberia ${ }^{35}$ improve the likelihood of realistic extrapolation compared to more heterogeneous regions, additional spatially distributed data on C fluxes are needed, particularly in the permafrost-free zone (Fig. 1). Furthermore, due to the region's flat terrain, Western Siberia has extensive floodplains and wetlands that increase substantially in water area during spring flood ${ }^{36,37}$. Assuming a maximal $85 \%^{36}$ increase in area over a period of 30 days, the $\mathrm{C}$ emission from inland waters of Western Siberia rises by $\sim 11 \%$. Our estimates also include uncertainties because of the lack of direct observations of smallest stream and pond areal distribution across the landscape. In particular, it has been recently suggested that contrary to stream area, pond area distribution in the landscape does not follow Pareto law ${ }^{31,38}$. Given this fact, we also adopted an alternative approach where we quantified pond $\mathrm{C}$ emission based on pond area derived from satellite image analysis of several sites within specific permafrost zones of Western Siberia $^{31}$. Our result obtained with this approach yielded a $\sim 31 \%$

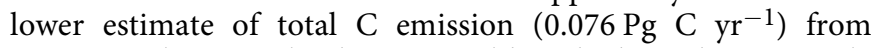
Western Siberian inland waters. Although these data are only based on a fraction of the basin, it still suggest a critical knowledge gap and the need for more detailed satellite inventories of pond area distribution across the landscape to assess their role in total inland water $\mathrm{C}$ emission. 

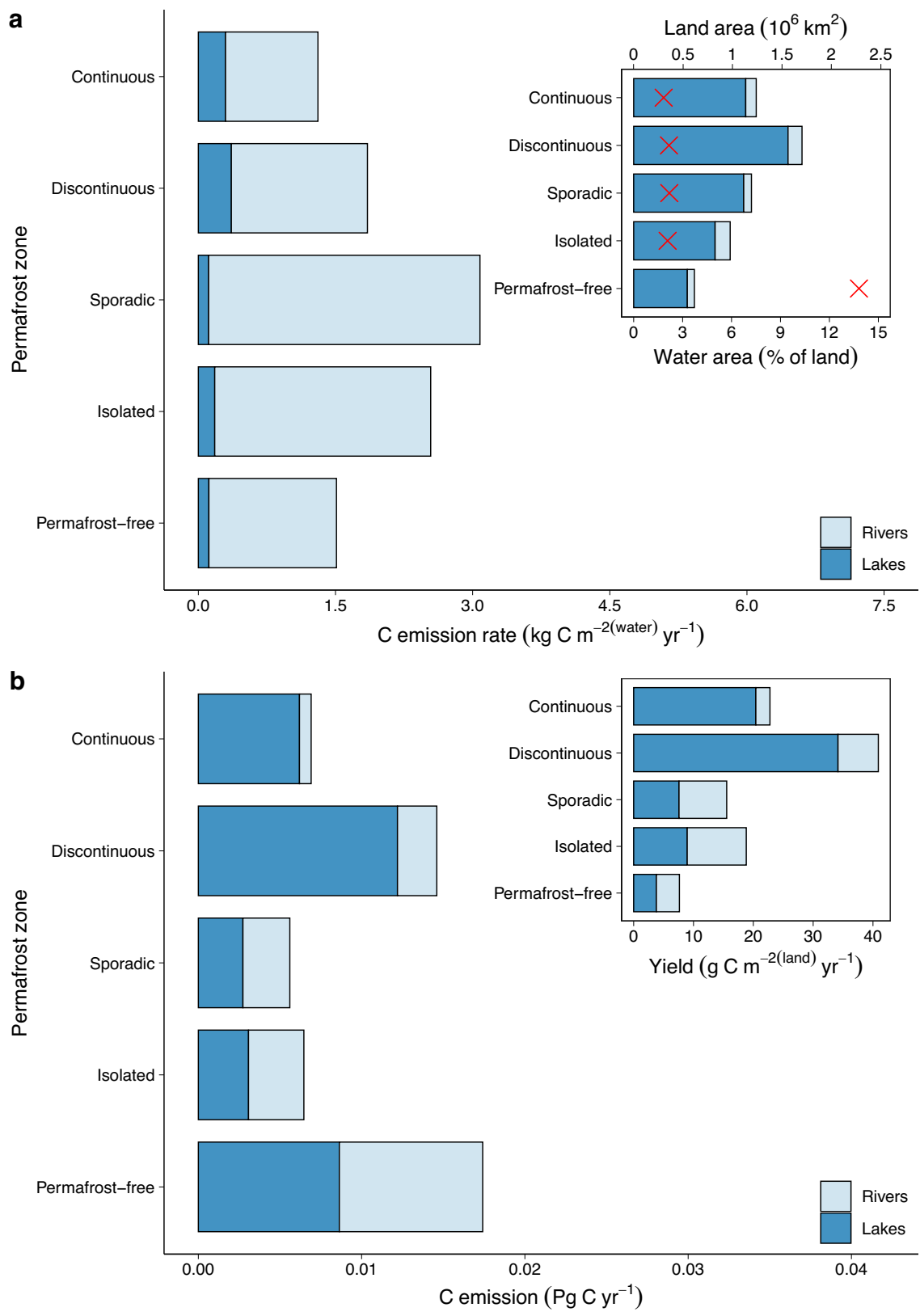

Fig. 2 Inland water carbon (C) flux dynamics across permafrost gradient of Western Siberia. a Annual $\mathbf{C}$ emission rates per unit aquatic area and surface area coverage (inset) of rivers and lakes. Red crosses (inset) represent land area. b Annual C emission and yield (inset) from rivers and lakes. The figure does not include the smallest streams and ponds. For uncertainties see text, Table 1, and Supplementary Table 1.

Table 1 Surface area and C emission (with associated uncertainties, see Methods) for inland waters of Western Siberia.

\begin{tabular}{|c|c|c|c|c|c|c|}
\hline C emission, $\mathrm{Pg} C \mathrm{yr}^{-1}$ & $0.004( \pm 0.001)$ & $0.013( \pm 0.003)$ & $0.013( \pm 0.003)$ & $0.024( \pm 0.006)$ & $0.008( \pm 0.002)$ & $0.039( \pm 0.010)$ \\
\hline
\end{tabular}

This study also highlights the complexity in assessments of contemporary and future $\mathrm{C}$ outgassing from inland waters. First, it stresses the need to account for variability in both $\mathrm{C}$ emission rates and surface areas of streams, rivers, ponds, and lakes across the landscape. Second, the observed patterns in $\mathrm{C}$ emission and yield (Fig. 2) suggest that $\mathrm{C}$ outgassing is controlled differently between inland waters, yet detailed mechanistic studies are generally lacking. Current knowledge of these systems indicates a strong sensitivity on climate-dependent processes for $\mathrm{C}$ outgassing, but not always as expected based on knowledge from other regions. In general, C emission from rivers has been explained as mainly driven by lateral input of terrestrial $\mathrm{C}$, and its subsequent mineralization and evasion from the water column ${ }^{27}$. These processes are largely controlled by temperature and water 
a

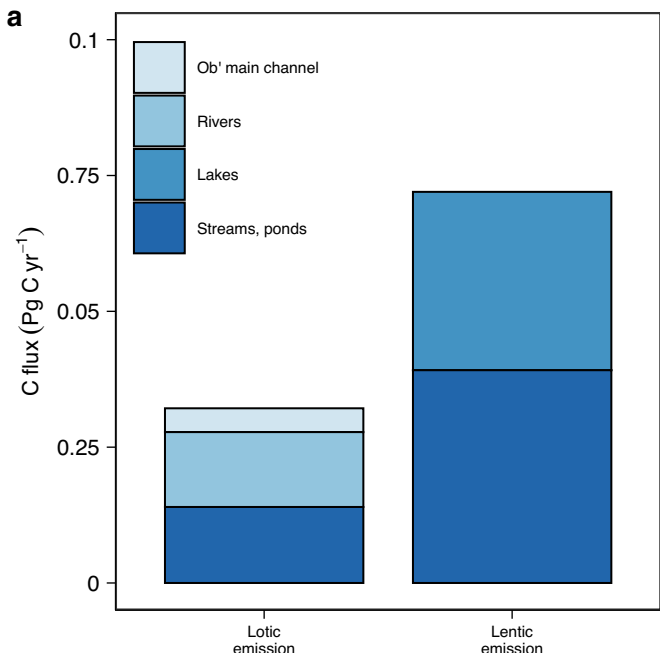

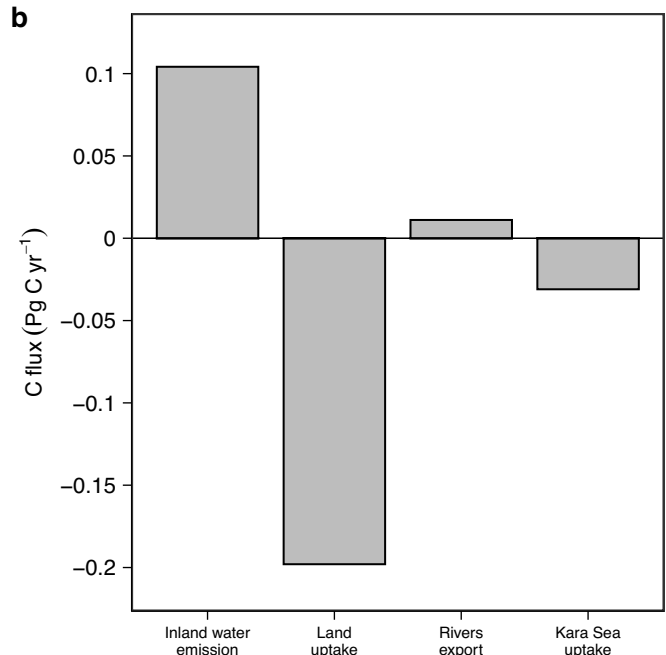

Fig. 3 Carbon (C) fluxes of Western Siberia. a Different components of inland water C emission (blue shading). b Total inland water C emission, land C uptake, rivers $\mathrm{C}$ export to the Arctic ocean, and $\mathrm{C}$ uptake by the Kara sea. For uncertainties see text. Negative emission rates represent net uptake of $\mathrm{CO}_{2}$.

transit times that result in nonlinear dynamics with elevated $\mathrm{C}$ emission rates in warm vs cold permafrost regions, but also lower rates in permafrost-free zone ${ }^{27}$. For ponds and lakes lateral inputs of terrestrial $\mathrm{C}$ seem less important for $\mathrm{C}$ outgassing because of the generally small catchments. Instead, high rates of $\mathrm{C}$ emission from ponds and lakes have mainly been attributed to the shallow depths that cause relatively high mineralization of terrestrial organic $\mathrm{C}$ in their bottom sediments, with elevated rates in cold permafrost-rich regions because of high organic $\mathrm{C}$ quality of recently thawed sediments and hampered algae $\mathrm{CO}_{2}$ fixation ${ }^{28}$. Importantly, warming likely changes the areal coverage of inland waters, chiefly for thaw ponds and lakes where spatiotemporal variability in losses and gains create large uncertainty in the net outcome ${ }^{3}$. The complexity in the control of $\mathrm{C}$ outgassing from inland waters, with multiple drivers that vary across systems, implies that predicting future $\mathrm{C}$ outgassing from inland waters of Western Siberia is fraught with large uncertainties that require an interdisciplinary approach.

To estimate the relative importance of Western Siberian inland water $\mathrm{C}$ emission, we compared the total inland water $\mathrm{C}$ emission (0.076-0.104 $\mathrm{Pg} \mathrm{C} \mathrm{yr}^{-1}$ ) with other components of the regional $\mathrm{C}$ cycle (Fig. 3). First, we quantified Western Siberian land C uptake using regional data on terrestrial net ecosystem exchange (NEE) during $2016^{39}$ to $-0.198 \pm 0.009 \mathrm{Pg} \mathrm{C} \mathrm{yr}^{-1}$ (Supplementary Fig. 1 and Supplementary Table 2). Thus, almost half (35-50\%) of land C uptake is released back to the atmosphere via inland waters, implying that neglecting inland waters will largely overestimate the $\mathrm{C}$ sink strength of the region. Second, we compiled published data on river dissolved organic and inorganic $C$ export to the Arctic Ocean (Ob' River: mean for the period of 2003-2009; Pur and Taz Rivers: mean for the period of 2013-2014) $)^{35,40-42}$

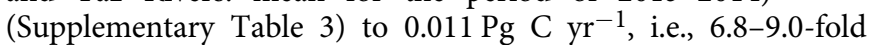
lower than $\mathrm{C}$ emission from inland waters. This implies that only $\sim 10 \%$ of the C lost laterally from land reaches the Arctic Ocean, the rest is largely processed and emitted to the atmosphere by inland waters. Third, we found that the inland water $\mathrm{C}$ emission was 2 2.4-3.0-times higher than the $\mathrm{C}$ uptake by the Kara Sea $\left(-0.031 \mathrm{Pg} \mathrm{C} \mathrm{yr}^{-1}\right.$ during 2014) ${ }^{43,44}$ into where all Western Siberian rivers discharge. Because of interannual variability in fluxes, these types of comparisons should optimally include multiyear overlapping time periods, and thus the exact numbers should be treated with caution. Despite the uncertainties, these results emphasize the important role of $\mathrm{C}$ emissions from inland waters in the regional land-water $\mathrm{C}$ cycle. Ignoring $\mathrm{C}$ outgassing from inland waters may largely underestimate the impact of warming on these regions and overlook their weakening capacity to act as terrestrial $C$ sinks. Although few coupled land-water $C$ cycle studies exist for comparison, these data suggest that the role of inland waters of $\mathrm{Ob}$ in the $\mathrm{C}$ cycle are particularly high compared to other large scale estimates at high latitudes $14,45,46$ and globally ${ }^{13,47}$, and are on par with estimates for the Tropics ${ }^{11,48}$. The high significance of the inland waters of Western Siberia in the $\mathrm{C}$ cycle is likely a result of the overall flat terrain, which leads to relatively high water coverage and long water transit times, and thus favorable conditions for mineralization and outgassing of land derived $C$ in inland waters ${ }^{27,28}$. Further studies on the coupled land-water $\mathrm{C}$ cycle are needed in order to improve the understanding of regional differences in the contemporary $\mathrm{C}$ cycle and predictions of future conditions in these understudied and climate-sensitive areas.

\section{Methods}

Inland water area estimates. We used available Global River Widths from Landsat $(\text { GRWL) })^{1}$ as well as Global Water Bodies (GLOWABO $)^{2}$ databases to estimate river and lake area in the Ob', Pur, and Taz River basins. We first clipped the databases' files to the respective area of Western Siberia using ArcMap 10.5. Then we overlaid GRWL river network with Ob' main channel mask derived from World Major Rivers file (https://www.arcgis.com/home/item. html?id=44e8358cf83a4b43bc863646cd695945) by selecting features that are within $\sim 20 \mathrm{~km}$ distance from the Ob' main channel mask, and clipped Ob' main channel from GRWL river network. We further separated the Ob' main channel, river, and lake files to the respective permafrost zones using shapefiles of the Circum-Arctic Map of Permafrost and Ground Ice Conditions (http://nsidc.org/ data/docs/fgdc/ggd318_map_circumarctic/). After that we merged the Ob' main channel, river, and lake files for each permafrost zone in R (version 3.5), making three individual continuous spatial datasets with all permafrost zones present (Ob' main channel spatial dataset consisting of 201,874 observations of river area, river spatial dataset of 882,124 observations of river area, and lake spatial dataset of 973,780 lakes). We excluded rivers $<90 \mathrm{~m}$ wide from both river and Ob' main channel datasets as done in Allen et al. ${ }^{1}$.

To include rivers and streams $<90 \mathrm{~m}$ not present in the GRWL database, we estimated their surface area using Pareto extrapolation based on the specific Pareto shape parameter of $0.93 \pm 0.0004$ ( \pm s.d.) reported for the rivers of Ob' River basin ${ }^{1}$ and the minimum width of the first-order streams of $0.32 \pm 0.077 \mathrm{~m}^{49}$. Similarly, to include ponds $<0.01 \mathrm{~km}^{2}$ not present in the GLOWABO database we used Pareto extrapolation based on the specific Pareto shape parameter of $1.19 \pm 0.0004$ for the lakes of Ob' River basin (obtained by fitting power law to Ob' basin lakes in GLOWABO) and the smallest measured pond area of $0.000115 \pm 0.0001 \mathrm{~km}^{2}$ (based on our field observations). There exist no data that enable to incorporate temporal variability in surface area across all systems and full region, and all areal estimates are assumed to represent average conditions over the open water season.

Since it has recently been suggested that contrary to stream area, pond area distribution in the landscape does not follow Pareto law ${ }^{31,38}$, we also quantified 
pond area using the fraction of land covered by these types of water bodies for each of the permafrost zones derived from lake satellite inventories of few sites within specific permafrost zones of the region from Muster et al. 201931. Since Muster et al. ${ }^{31}$ estimated lake area (including ponds $>0.0001 \mathrm{~km}^{2}$ ) in one site in the sporadic permafrost zone and in two sites in the continuous permafrost zone, we assumed the fraction of land covered by ponds in permafrost-free and isolated permafrost zones being similar to the sporadic permafrost zone (where ponds occupy $\sim 2.9 \%$ of land), while the fraction of land covered by ponds in the discontinuous permafrost zone being similar to the average fraction of land covered by such water bodies between the two sites in the continuous permafrost zone $(\sim 0.62 \%$ of land).

Ancillary data. We used published data on annual flow-weighted dissolved organic C (DOC) ${ }^{35,40}$ and dissolved inorganic C (DIC) ${ }^{41,42}$ export to the Arctic ocean during 2003-2009 for the Ob' River, as well as annual flow-weighted DOC and DIC ${ }^{41,42}$ export (mean for the period of 2013-2014 quantified based on discharge data over the period 1971-1980) for Pur and Taz Rivers and summed them together to obtain the downstream C export for this region (Supplementary Table 3). We also estimated season length across entire region of Western Siberia by using a linear relationship between latitude $\left({ }^{\circ} \mathrm{N}\right)$ and number of ice-free season days published for rivers ${ }^{27}$ and lakes $^{28}$.

C emission from $\mathbf{O b}$ ' main channel. The $\mathrm{pCO}_{2}$ of $\mathrm{Ob}^{\prime}$ main channel was collected at $0.5 \mathrm{~m}$ depth every minute during $5 \mathrm{~min}$ at 10 -min interval (yielding 4938 measurements) from a ship in summer 2016 (31 July to 11 August) by an infrared gas analyzer (Vaisala GMP222; accuracy $\pm 1.5 \%$ ) connected to a Campbell logger. The probe was calibrated in the lab and the $p \mathrm{CO}_{2}$ data were corrected for pressure and temperature (collected at same frequency) as described in Serikova et al. ${ }^{27}$. We estimated molar concentrations of $p \mathrm{CO}_{2}$ in water and in water in equilibrium with the atmosphere using Henry's constant and pressure, and the average atmospheric concentration of $390 \mathrm{ppm}$. We grouped measurements and calculated the total $\mathrm{CO}_{2}$ evasion in each permafrost zone (permafrost-free, isolated, sporadic, discontinuous, and continuous). Since we lacked values in the continuous permafrost zone (because the ship finished sampling before reaching the Ob' River mouth in the continuous permafrost zone), we used the values from the adjacent discontinuous permafrost zone. In total, we obtained $4396 \mathrm{pCO}_{2}$ measurements in the $\mathrm{Ob}^{\prime}$ main channel, the number of measurements in each permafrost zone were 1516, 1982, 431, and 467 in the absent, isolated, sporadic, and discontinuous permafrost zones, respectively. To calculate the total $\mathrm{CO}_{2}$ evasion for each permafrost zone, we performed a Monte Carlo simulation by randomly sampling the observations of $p \mathrm{CO}_{2}$ in the water, $p \mathrm{CO}_{2}$ in the atmosphere and $\mathrm{pH} 100,000$ times. The $\mathrm{pH}$ values for the respective permafrost zones were derived from our published river seasonal data ${ }^{27}$, truncating $\mathrm{pH}$ values to $<8$ because observed seasonal river $\mathrm{pH}$ values never exceeded a $\mathrm{pH}$ value of $8^{27}$. Thus, $\mathrm{CO}_{2}$ emissions were calculated as:

$$
\mathrm{CO}_{2} \text { emission rate }=\alpha \times \text { median }(k) \times\left(p \mathrm{CO}_{2 \text { water }}-p \mathrm{CO}_{2 \text { atmosphere }}\right) \times 10^{-6}
$$

where $\alpha$ is the $\mathrm{pH}$-dependent chemical enhancement factor of $\mathrm{CO}_{2}{ }^{50}, k$ is a median gas transfer coefficient of $4.464 \mathrm{~m} \mathrm{~d}^{-1}$ measured in four largest rivers (June 2015) of the Ob', Pur, Pyakupur, and Taz Rivers $(\mathrm{n}=39$, each consisting of multiple measurements with floating chamber drifting in the middle of the river channel for $5 \mathrm{~min}), p \mathrm{CO}_{2}$ water is assigned $p \mathrm{CO}_{2}$ in the water and $p \mathrm{CO}_{2}$ atmosphere is the assigned $p \mathrm{CO}_{2}$ in water in equilibrium with the atmosphere. To obtain the total yearly $\mathrm{CO}_{2}$ emissions in each permafrost zone, we multiplied the areal $\mathrm{CO}_{2}$ emission rate by the total river area in each permafrost zone, as well as the average ice-free season length based previous measurements within permafrost zones ${ }^{27}$. Furthermore, given our observations on seasonality in $p \mathrm{CO}_{2}$ concentrations in the $\mathrm{Ob}^{\prime}$ main channel from our previous work ${ }^{27}$ and considering that the ship $p \mathrm{CO}_{2}$ data sampling took place in July-August, we increased assigned $p \mathrm{CO}_{2}$ values (that represent summer $p \mathrm{CO}_{2}$ ) by a factor of 2 to get the approximate $p \mathrm{CO}_{2}$ in the spring, and took the average between them for quantifying daily rates of $\mathrm{CO}_{2}$ outgassing during open water period (May-October).

We estimated daily rate of $\mathrm{CH}_{4}$ outgassing for each of the points by using the median fraction of $\mathrm{CH}_{4}$ in $\mathrm{C}$ emission rate from our river data ${ }^{27}$ equal to $1.19 \%$ and summed up $\mathrm{CO}_{2}$ and $\mathrm{CH}_{4}$ emission rates to get the $\mathrm{C}\left(\mathrm{CO}_{2}+\mathrm{CH}_{4}\right)$ emission rate (Supplementary Fig. 2). After that we multiplied $\mathrm{C}$ emission rate with respective season length and water areas for each of the data points, and summed all points together. We also added land area to different permafrost zones based on Circum-Arctic Map of Permafrost and Ground Ice Conditions $s^{51}$ and estimated C yield for each of the data points by normalizing the $\mathrm{C}$ emission rate to the respective land area.

C emission from rivers and streams. To quantify $\mathrm{C}$ emission for rivers, we used published data on daily rates of $\mathrm{CO}_{2}$ outgassing from 58 rivers $(n=116)^{27}$. We created five normal distributions with $\mathrm{CO}_{2}$ emission rates for each permafrost zones with 10,000 values in each using the mean and s.d. for the respective permafrost zones from the observed $\mathrm{CO}_{2}$ emission rates river data (Supplementary Table 1). Then, for each observation of river area $(n=882,124)$, we randomly assigned a $\mathrm{CO}_{2}$ emission rate by subsampling the permafrost-specific distribution of emission rates defined above. After that we estimated daily rates of $\mathrm{CH}_{4}$ (i.e., $1.19 \%$ of total C emission) and C emission using the same approach as for $\mathrm{Ob}^{\prime}$ main channel. Then we estimated season length for each data point using the linear regression with latitude $\left(R^{2}=0.99, F_{1,114}=7899.51, p<0.01\right.$, Supplementary Table 4), and multiplied daily $\mathrm{C}$ emission rate with season length and water areas for each of the data points. Finally, we summed all points together to get the total $C$ emission for rivers. We also added land area to different permafrost zones following the same approach as for the Ob' main channel and estimated C yield. We quantified $\mathrm{C}$ emission for streams using the published ${ }^{27}$ median $\mathrm{C}$ emission rate of $5.67 \mathrm{~g} \mathrm{C} \mathrm{m}^{-2} \mathrm{~d}^{-1}$ for watersheds $<100 \mathrm{~km}^{2}$ (assuming the same $1.19 \%$ fraction of $\mathrm{CH}_{4}$ in $\mathrm{C}$ emission rate). We then multiplied this value with extrapolated stream area and a median season length of 180.6 days was observed in our river data ${ }^{27}$.

C emission from lakes and ponds. For permafrost-affected lakes we used published lake $\mathrm{C}\left(\mathrm{CO}_{2}+\right.$ diffusive $\left.\mathrm{CH}_{4}\right)$ emission rates data (76 lakes, $n=228$, Supplementary Fig. 3$)^{28}$. Since we did not observe linear dependence of $\mathrm{C}$ emission rates with lake size $\left(n=182, R^{2}=0.00, F_{1,179}=0.598, p>0.05\right)$, we utilized a similar approach for upscaling $\mathrm{C}$ emission rates as in river upscaling. We created five normal distributions with $\mathrm{C}$ emission rates data representing different permafrost zones with 10,000 values in each using mean and s.d. for the respective permafrost zones from lake data (Supplementary Table 1$)^{28}$. Then, for each observation $(n=612,003)$, we randomly assigned a $\mathrm{CO}_{2}$ emission rate by subsampling the permafrost-specific distribution of emission rates defined above. Then we estimated season length for each data point using the linear regression with latitude $\left(R^{2}=0.96, F_{1226}=6012.09, p<0.01\right.$, Supplementary Table 1$)$, and multiplied daily $\mathrm{C}$ emission rate with season length and water areas for each of the data points. Finally, we summed all points together to get the total $\mathrm{C}$ emission for permafrost-affected lakes. We also estimated $\mathrm{C}$ yield following methods described above. When quantifying $\mathrm{C}$ emission for lakes in the permafrost-free zone, we used published $\mathrm{C}$ emission rates from 13 permafrost-free lakes $(n=13)^{29}$. Considering that the linear dependence of $\mathrm{C}\left(\mathrm{CO}_{2}+\right.$ diffusive $\left.\mathrm{CH}_{4}\right)$ emission rates on lake size in permafrost-free area was very weak $\left(\log _{10}\right.$-transformed, $n=13, R^{2}=0.20$, $\left.F_{1,11}=2.801, p>0.05\right)$, we used the median C emission rate of $0.6 \mathrm{~g} \mathrm{C} \mathrm{m}^{-2} \mathrm{~d}^{-1}$ when upscaling to lakes $(n=361,777)$ located in permafrost-free area of Western Siberia (using same approach as described above for permafrost-affected lakes). We also estimated $\mathrm{C}$ yield using the same approach as above. We quantified $\mathrm{C}$ emission for ponds using the published median $\mathrm{C}$ emission rate for permafrost-affected $\left(1.12 \mathrm{~g} \mathrm{C} \mathrm{m}^{-2} \mathrm{~d}^{-1}\right)$ and permafrost-free $\left(0.6 \mathrm{~g} \mathrm{C} \mathrm{m}^{-2} \mathrm{~d}^{-1}\right)$ smallest size class lakes of Western Siberia, and multiplied this with extrapolated pond area and median season length for respective region. Since it has been recently suggested that pond area distribution in the landscape does not follow Pareto law 31,38 , we also quantified $\mathrm{C}$ emission for ponds using the fraction of land covered by these water bodies types for each of the permafrost zone derived from dataset available in Muster et al. ${ }^{31}$. Following this approach the total $\mathrm{C}$ emission for ponds is $\sim 3.4$-fold lower.

Uncertainty in C emission estimates. The uncertainty in C emission rates values for the Ob' main channel was estimated using a Monte Carlo approach. We randomly subsampled ten times 1000 values of each of the following variables: $p \mathrm{CO}_{2}$ water, $p \mathrm{CO}_{2}$ atmosphere, $k$ and chemical enhancement factor, and estimated $\mathrm{C}$ emission rates as above. Using this approach, the mean $\mathrm{C}$ emission rate for $\mathrm{Ob}^{\prime}$ main channel is $\sim 1.8$-fold greater compared to the mean quantified $\mathrm{C}$ emission rate, whereas the median values are almost identical (Supplementary Fig. 4). To assess uncertainty in $\mathrm{C}$ emission from different components of inland waters in a uniform way, we used the standard rules of error propagation. We assumed $15 \%$ uncertainty in estimates of key variables (C emission rates, water areas, and season length) and propagated our error following:

$$
\delta R=|R|+\sqrt{\left(\frac{\delta x}{x}\right)^{2}+\left(\frac{\delta y}{y}\right)^{2}+\left(\frac{\delta z}{z}\right)^{2}}
$$

where $\delta R$ is the uncertainty, $R$ is a result of multiplication of $C$ emission rates, water areas, and season lengths, while $\delta x, \delta y$, and $\delta z$ are $15 \%$ uncertainty estimates of $\mathrm{C}$ emission rates $(x)$, water areas $(y)$, and season lengths $(z)$, respectively. We then estimated the uncertainties for total river and lake $\mathrm{C}$ emission as well as total $\mathrm{C}$ emission from inland waters (rivers, streams, lakes, ponds) as follows:

$$
\delta R=\sqrt{(\delta x)^{2}+(\delta y)^{2}+(\delta z)^{2}+\ldots}
$$

where $\delta R$ is the total uncertainty, while $\delta x, \delta y$, and $\delta z, \ldots$ are $\mathrm{C}$ emission uncertainties estimated for each of the inland water components from Eq. (2).

Statistics. We examined differences in inland water $\mathrm{C}$ emission and $\mathrm{C}$ yield (rivers + lakes, excluding streams and ponds) between different permafrost zones of Western Siberia with Kruskal-Wallis test on randomly subsampled 500 values. We considered the result statistically significant at $p<0.05$.

Net ecosystem exchange data. We used NASA SMAP L4 Global Daily $9 \mathrm{~km}$ EASE-Grid Carbon Net Ecosystem Exchange, Version 4 product $^{39}$ (https://nsidc. org/data/SPL4CMDL) to quantify monthly and annual rates of NEE across Western Siberia. This product provides global gridded $(9 \times 9 \mathrm{~km})$ daily estimates of 
NEE $\left(\mathrm{CO}_{2}\right)$ derived using satellite data based on terrestrial $\mathrm{C}$ flux model informed by Soil Moisture Active Passive (SMAP) L-band microwave observations, land cover and vegetation inputs from the Moderate Resolution Imaging Spectroradiometer, Visible Infrared Imaging Radiometer Suite, and the Goddard Earth Observing System Model, Version 5 land model assimilation system. Note that NEE detects only terrestrial vegetation and ignores aquatic surfaces. We downloaded the data files covering the full year of 2016. Note that our sampling campaign on lakes was conducted during open water period (May-October) 2016 and the Ob River was studied in July-August 2016. We imported these data files to R, extracted the mean NEE rate as well as 1 s.d. of the mean NEE rate data from these data files (representing in total 730 individual data of $\mathrm{h} 5$ format), projected them, converted them to GeoTiff format, and clipped the area matching the location of Ob', Pur, and Taz River basins (Supplementary Fig. 1). We then quantified the mean NEE rate and mean s.d. across all 71,280 of $9 \times 9 \mathrm{~km}$ cells covering the region, for each day separately, and after that we estimated the NEE for entire Western Siberia as a sum of products of each 71,280 individual cells' NEE rates and respective cells' resolution (also for each day separately). The monthly NEE and annual NEE were quantified as the sum of daily and monthly NEE, respectively (Supplementary Table 2). We assessed uncertainty in monthly and annual NEE using Eqs. (2) and (3).

Net $\mathrm{C}$ uptake by the Kara Sea. To estimate net $\mathrm{C}$ uptake by the Kara Sea, we used published grid $(1 \times 1$ degree $)$ data for $\mathrm{CO}_{2}$ uptake by the Arctic Ocean $\left(60-90^{\circ} \mathrm{N}\right.$, $0^{\circ}-360^{\circ}$ ) for year $2014^{43,44}$ (http://www.jamstec.go.jp/res/ress/yasunaka/co2flux/\#! prettyPhoto). We downloaded the data file, imported it to $\mathrm{R}$, and clipped the grid cells matching the GPS boundaries of the Kara Sea (2784 observations). We then quantified the mean annual $\mathrm{CO}_{2}$ uptake rate encoded in these grid cells $\left(-7.64 \mathrm{mmol} \mathrm{m}^{-2} \mathrm{~d}^{-1}\right.$, from January to December) and multiplied it by the water surface area of the Kara Sea and by 365 days (as done in Yasunaka et al. ${ }^{44}$ ).

\section{Data availability}

The datasets generated during this study are available in the ZENODO repository: https://doi.org/10.5281/zenodo.4153049.

\section{Code availability}

Code for data analysis (for terrestrial NEE) is available upon request.

Received: 25 May 2020; Accepted: 11 January 2021;

Published online: 05 February 2021

\section{References}

1. Allen, G. H. \& Pavelsky, T. M. Global extent of rivers and streams. Science 361, 585-587 (2018)

2. Verpoorter, C., Kutser, T., Seekell, D. A. \& Tranvik, L. J. A global inventory of lakes based on high-resolution satellite imagery. Geophys. Res. Lett. 41, 6396-6402 (2014).

3. Vonk, J. E. et al. Reviews and syntheses: effects of permafrost thaw on Arctic aquatic ecosystems. Biogeosciences 12, 7129-7167 (2015).

4. Ciais, P. et al. Carbon and other biogeochemical cycles. Climate change 2013-The Physical Science Basis. Contribution of Working Group I to the Fifth Assessment Report of the Intergovernmental Panel on Climate Change. 465-570 (2013).

5. Tarnocai, C. et al. Soil organic carbon pools in the northern circumpolar permafrost region. Global Biogeochemical Cycles 23, https://doi.org/10.1029/ 2008gb003327 (2009)

6. Schuur, E. A. G. et al. Climate change and the permafrost carbon feedback. Nature 520, 171-179 (2015).

7. Chadburn, S. E. et al. An observation-based constraint on permafrost loss as a function of global warming. Nat. Clim. Change 7, 340 (2017).

8. Wauthy, M. et al. Increasing dominance of terrigenous organic matter in circumpolar freshwaters due to permafrost thaw. Limnol. Oceanogr. Lett. 3 , 186-198 (2018).

9. Feng, X. J. et al. Differential mobilization of terrestrial carbon pools in Eurasian Arctic river basins. Proc. Natl Acad. Sci. USA 110, 14168-14173 (2013).

10. Raymond, P. A. et al. Global carbon dioxide emissions from inland waters. Nature 503, 355-359 (2013).

11. Richey, J. E., Melack, J. M., Aufdenkampe, A. K., Ballester, V. M. \& Hess, L. L. Outgassing from Amazonian rivers and wetlands as a large tropical source of atmospheric CO2. Nature 416, 617-620 (2002).

12. Cole, J. J. et al. Plumbing the global carbon cycle: Integrating inland waters into the terrestrial carbon budget. Ecosystems 10, 172-185 (2007).

13. Battin, T. J. et al. The boundless carbon cycle. Nat. Geosci. 2, 598-600 (2009).
14. Stackpoole, S. M. et al. Inland waters and their role in the carbon cycle of Alaska. Ecol. Appl. 27, 1403-1420 (2017).

15. Kling, G. W., Kipphut, G. W. \& Miller, M. C. The flux of $\mathrm{CO}_{2}$ and $\mathrm{CH}_{4}$ from lakes and rivers in Arctic Alaska. Hydrobiologia 240, 23-36 (1992).

16. Kuhn, M., Lundin, E. J., Giesler, R., Johansson, M. \& Karlsson, J. Emissions from thaw ponds largely offset the carbon sink of northern permafrost wetlands. Scientific Reports 8, https://doi.org/10.1038/s41598-018-27770-x (2018).

17. Lundin, E. J. et al. Is the subarctic landscape still a carbon sink? Evidence from a detailed catchment balance. Geophys. Res. Lett. 43, 1988-1995 (2016).

18. Ciais, P. et al. Five decades of northern land carbon uptake revealed by the interhemispheric CO2 gradient. Nature 568, 221 (2019).

19. Sheng, Y. W. et al. A high-resolution GIS-based inventory of the west Siberian peat carbon pool. Global Biogeochemical Cycles 18, https://doi.org/10.1029/ 2003gb002190 (2004).

20. Smith, L. C. et al. Siberian peatlands a net carbon sink and global methane source since the early Holocene. Science 303, 353-356 (2004).

21. Romanovsky, V. E. et al. Thermal state of permafrost in Russia. Permafr. Periglac. Process. 21, 136-155 (2010).

22. Frappart, F. et al. Interannual variations of the terrestrial water storage in the Lower Ob' Basin from a multisatellite approach. Hydrol. Earth Syst. Sci. 14, 2443-2453 (2010).

23. Klaus, M. \& Vachon, D. Challenges of predicting gas transfer velocity from wind measurements over global lakes. Aquatic Sciences 82, https://doi.org/ 10.1007/s00027-020-00729-9 (2020).

24. Denfeld, B. A., Baulch, H. M., del Giorgio, P. A., Hampton, S. E. \& Karlsson, J. A synthesis of carbon dioxide and methane dynamics during the ice-covered period of northern lakes. Limnol. Oceanogr. Lett. 3, 117-131 (2018).

25. Abril, G. et al. Technical note: large overestimation of $\mathrm{pCO}(2)$ calculated from $\mathrm{pH}$ and alkalinity in acidic, organic-rich freshwaters. Biogeosciences 12, 67-78 (2015).

26. Klaus, M., Seekell, D. A., Lidberg, W. \& Karlsson, J. Evaluations of climate and land management effects on lake carbon cycling need to account temporal variability in CO2 concentration. Glob. Biogeochemical Cycles 33, 243-265 (2019).

27. Serikova, S. et al. High riverine $\mathrm{CO}_{2}$ emissions at the permafrost boundary of Western Siberia. Nat. Geosci. 11, 825 (2018).

28. Serikova, S. et al. High carbon emissions from thermokarst lakes of Western Siberia. Nat. Commun. 10, https://doi.org/10.1038/s41467-019-09592-1 (2019).

29. Sabrekov, A. F. et al. Variability in methane emissions from West Siberia's shallow boreal lakes on a regional scale and its environmental controls. Biogeosciences 14, 3715-3742 (2017)

30. Messager, M. L., Lehner, B., Grill, G., Nedeva, I. \& Schmitt, O. Estimating the volume and age of water stored in global lakes using a geo-statistical approach Nat. Commun. 7, https://doi.org/10.1038/ncomms13603 (2016).

31. Muster, S. et al. Size distributions of Arctic waterbodies reveal consistent relations in their statistical moments in space and time. Front. Earth Sci. 7, https://doi.org/10.3389/feart.2019.00005 (2019).

32. Holgerson, M. A. \& Raymond, P. A. Large contribution to inland water $\mathrm{CO} 2$ and CH4 emissions from very small ponds. Nat. Geosci. 9, 222-U150 (2016).

33. Lauerwald, R., Laruelle, G. G., Hartmann, J., Ciais, P. \& Regnier, P. A. G. Spatial patterns in $\mathrm{CO} 2$ evasion from the global river network. Glob. Biogeochemical Cycles 29, 534-554 (2015).

34. Campeau, A., Lapierre, J. F., Vachon, D. \& del Giorgio, P. A. Regional contribution of $\mathrm{CO} 2$ and $\mathrm{CH} 4$ fluxes from the fluvial network in a lowland boreal landscape of Quebec. Glob. Biogeochemical Cycles 28, 57-69 (2014).

35. Pokrovsky, O. S. et al. Permafrost coverage, watershed area and season control of dissolved carbon and major elements in western Siberian rivers. Biogeosciences 12, 6301-6320 (2015)

36. Zakharova, E. A. A. et al. The modern hydrological regime of the northern part of Western Siberia from in situ and satellite observations. Int. J. Environ. Stud. 66, 447-463 (2009).

37. Zakharova, E. A., Kouraev, A. V., Remy, F., Zemtsov, V. A. \& Kirpotin, S. N. Seasonal variability of the Western Siberia wetlands from satellite radar altimetry. J. Hydrol. 512, 366-378 (2014).

38. Polishchuk, Y. M. et al. Minor contribution of small thaw ponds to the pools of carbon and methane in the inland waters of the permafrost-affected part of the Western Siberian Lowland. Environ. Res. Lett. 13, https://doi.org/10.1088/ 1748-9326/aab046 (2018)

39. Kimball, J. S., Jones, L. A., Kundig, T. \& Reichle, R. SMAP L4 Global Daily 9 km EASE-Grid Carbon Net Ecosystem Exchange, Version 4. https://doi.org/ 10.5067/9831N0JGVAF6 (2018).

40. Kaiser, K., Canedo-Oropeza, M., McMahon, R. \& Amon, R. M. W. Origins and transformations of dissolved organic matter in large Arctic rivers. Sci. Rep. 7, https://doi.org/10.1038/s41598-017-12729-1 (2017).

41. Gordeev, V. V., Martin, J. M., Sidorov, I. S. \& Sidorova, M. V. A reassessment of the Eurasian river input of water, sediment, major elements, and nutrients to the Arctic Ocean. Am. J. Sci. 296, 664-691 (1996). 
42. Tank, S. E. et al. A land-to-ocean perspective on the magnitude, source and implication of DIC flux from major Arctic rivers to the Arctic Ocean. Global Biogeochem. Cycles 26, https://doi.org/10.1029/2011gb004192 (2012).

43. Yasunaka, S. et al. Mapping of the air-sea CO2 flux in the Arctic Ocean and its adjacent seas: basin-wide distribution and seasonal to interannual variability. Polar Sci. 10, 323-334 (2016).

44. Yasunaka, S. et al. Arctic Ocean CO2 uptake: an improved multiyear estimate of the air-sea CO2 flux incorporating chlorophyll a concentrations. Biogeosciences 15, 1643-1661 (2018).

45. Kling, G. W., Kipphut, G. W. \& Miller, M. C. Arctic lakes and streams as gas conduits to the atmosphere-implications for tundra carbon budgets. Science 251, 298-301 (1991).

46. Hastie, A. et al. CO2 evasion from boreal lakes: revised estimate, drivers of spatial variability, and future projections. Glob. Change Biol. 24, 711-728 (2018).

47. Drake, T. W., Raymond, P. A. \& Spencer, R. G. M. Terrestrial carbon inputs to inland waters: a current synthesis of estimates and uncertainty. Limnol. Oceanogr. Lett. 3, 132-142 (2018).

48. Borges, A. V. et al. Globally significant greenhouse-gas emissions from African inland waters. Nat. Geosci. 8, 637 (2015).

49. Allen, G. H. et al. Similarity of stream width distributions across headwater systems. Nat. Commun. 9, https://doi.org/10.1038/s41467-018-02991-w (2018).

50. Kuss, J. \& Schneider, B. Chemical enhancement of the $\mathrm{CO}_{2}$ gas exchange at a smooth seawater surface. Mar. Chem. 91, 165-174 (2004).

51. Brown, J., Ferrians, O., Heginbottom, J. A. \& Melnikov, E. Circum-Arctic map of permafrost and ground-ice conditions, Version 2, https://doi.org/10.7265/ skbg-kf16. (2002).

\section{Acknowledgements}

We thank Erik Geibrink for technical support and @AndreJ (https:/gis.stackexchange com/questions/253923/how-to-fix-the-reprojection-from-ease-2-grid-product-smap-togeographic-coordina) for providing valuable code ideas for working with NASA NEE data. The work was financially supported by the Swedish Research Council (grant no. 2016-05275 and 325-2014-6898, JPI Climate initiative) and RSF (grant no. 18-17-00237).

\section{Author contributions}

J.K. and O.S.P. conceived the study, S.N.V. collected the Ob' main channel $p \mathrm{CO}_{2}$ data, S.S. collected rivers and lakes $\mathrm{C}$ emission rates data and analyzed all data, G.R.-R. and
B.D. assisted in data analysis. J.K. and S.S. wrote the manuscript with input from all coauthors.

\section{Funding}

Open Access funding provided by Umea University.

\section{Competing interests}

The authors declare no competing interests.

\section{Additional information}

Supplementary information The online version contains supplementary material available at https://doi.org/10.1038/s41467-021-21054-1.

Correspondence and requests for materials should be addressed to J.K.

Peer review information Nature Communications thanks Jonathan Cole and other, anonymous, reviewers for their contributions to the peer review of this work.

Reprints and permission information is available at http://www.nature.com/reprints

Publisher's note Springer Nature remains neutral with regard to jurisdictional claims in published maps and institutional affiliations.

\section{(c) (1)}

Open Access This article is licensed under a Creative Commons Attribution 4.0 International License, which permits use, sharing, adaptation, distribution and reproduction in any medium or format, as long as you give appropriate credit to the original author(s) and the source, provide a link to the Creative Commons license, and indicate if changes were made. The images or other third party material in this article are included in the article's Creative Commons license, unless indicated otherwise in a credit line to the material. If material is not included in the article's Creative Commons license and your intended use is not permitted by statutory regulation or exceeds the permitted use, you will need to obtain permission directly from the copyright holder. To view a copy of this license, visit http://creativecommons.org/ licenses/by/4.0/.

(C) The Author(s) 2021 